\title{
DESIGN LESSONS FROM RECENT DESTRUCTIVE EARTHQUAKES
}

\author{
R. I. Skinner*
}

\section{Introduction}

Recent severe earthquakes have selectively damaged or destroyed inany large modern buildings. The destructive earthquakes at Caracas in Venezuela, July 1967, near Tokachi-oki in northern Japan, May 1968, and the two earthquakes at Manila in the Philippines, August 1968 and April 1970, have all highlighted important factors which should be considered during the earthquake-resistant design of buildings. Reports on these earthquakes which directly supplement this paper are listed in the references.

Very severe microzone effects were caused by areas of alluvium in Caracas and in Manila. Since tall buildings were selectively attacked microzone effects will be observed more frequent. ly as high-rise buildings proliferate.

Many buildings had their response to earth. quakes dominated by 1 ow-strength panels. In almost all cases these panels seriously reduced earthquake resistance, and they frequently suffered expensive non-structural damage. Some of the stronger "nonsstructural" panels completely destroyed adjacent columns while others caused severe diagonal tension cracks in columns。

The earlier Manila earthquake demonstrated that short shear walls may increase considerably the earthquake resistance of frame buildings. Such short shear walls were introduced to strengthen a number of the buildings which required repair after the earlier Manila earthquake, and the value of the se added shear walls was confirmed during the later earthquake. There is evidently some advantage in introducing such shear walls during the earthquake-resistant design of many frame buildings.

The buildings damaged and destroyed in Caracas were designed under a code which was based upon the Zone 2 provisions of the Uniform Building Code of California, 1955.

The 2 to 4 storey buildings damaged or destroyed by the Tokachi-oki earthquake were designed according to the existing Japanese code which called for earthquake design loads of 0.18 of gravity. Although the building code for Manila did not require specific attention to earthquake-resistant design for buildings less than 100 feet high, engineers were generally aware of earthquake problems and frequently designed for earthquake resistance. However many building designs appeared to follow the American Concrete Institute provisions for non-

* Head, Engineering Seismology Section, Physics and Engineering Laboratory, Lower Hutt. seismic areas.

\section{Microzone Effects}

During destructive earthquakes in Caracas and Manila there have been pronounced microzon effects in the damage inflicted on modern mult storey buildings. There was no ground damage during the July 1967 earthquake at Caracas and none during the August 1968 and the April 1970 earthquakes at Manila. Local increases of damage were therefore due to local increases in the inertia attack arising from ground acceleration. Despite substantial differences in the character of the two Manila earthquakes they both delineated the same microzone areas.

Some recent earthquakes have had local areas of severe damage caused by soil rupture or liquefaction. The inertia attack may not have varied much throughout Anchorage during the very severe earthquake of March 1964. How ever part of the city was destroyed by rupture and slipping of the ground near the edge of the plateau on which it stood. During the June 1964 earthquake at Niigata City there was sever local damage due to liquefaction of local uncon solidated silts. There were also areas of soil liquefaction during the Tokachi-oki earthquake. Some soils in Manila city are similar to those which liquefied during the Niigata and Tokachioki earthquakes and it is probable that they al so will liquefy if subjected to a very severe earthquake.

Caracas city was uniquely qualified to demonstrate microzone effects in the earthquake attack on tall buildings since it contained over 1000 modern buildings of 10 or more storeys, designed to resist moderately severe earthquakes, all with the same basic form of construction, and situated on a wide range of ground types from areas with 300 feet of alluvi to areas with surface rock. Since the epicentr of the 1967 earthquake was some 45 miles northnorth-west of the city all points within it were effectively equidistant from the epicentre

The main inertia attack at Caracas was to those buildings with 10 to 20 storeys which were situated in an area which contained alluvium to a depth of about 300 feet. Almost identical buildings in areas with a small depth of alluvium and in areas with surface rock suffered little or no damage. In the area of deep alluvium four buildings of 10 to 12 storey collapsed, a number of 10 to 20 storeys were close to collapse and many of 10 to 20 storeys were severely damaged.

The Caracas earthquake of 1967 appeared to provide all the conditions necessary to give very pronounced local variations in the inertia 
attack. The earthquake was distant ( 45 miles) and of large magnitude (6.5, Richter) so that rock vibrations would have a moderate intensity and relatively long periods. The city contained an area of deep flexible alluvium with well defined boundaries and also areas with shallow alluvium and with surface rock. The alluvium would have had a severe resonance at a well defined period. The relatively low strains would have limited energy losses and changes of resonant period. The tall buildings were rendered more vulnerable to attack by panels which usually limited structural damage to first storey columns. The limited region of damage in the buildings reduced the plastic reserve and prevented large changes in the building period. These soil and building characteristics could be expected to give a severe and period-selective attack on the tall buildings.

In some areas of Caracas, where the alluvium was of intermediate depth, there was considerabie damage to buildings a few storeys high. However one and two-storey buildings did not suffer significant damage anywhere in the city.

Many of the factors which gave severe microzone effects in Caracas were also present in Manila. The earthquakes were distant (about 170 and 150 miles) and of large magnitude (about 7.2 Richter)。 There was an area with very soft alluvium down to 100 to $140 \mathrm{feet}$. However large buildings in Manila had a much wider range in types of construction than those in Caracas and some were more than 50 years old. In Manila the very severe damage and the two collapsed buildings were confined to the area of deep alluvium, with the most severe attacks on buildings of 6 to 10 storeys in August 1968 and on buildings of 3 to 10 storeys in April 1970. Despite the similar bearings and distances to the epicentres of the two earthquakes there were considerable differences in the character of the attack, the second being quite directional and extending to shorter periods than the first. However during both earthquakes the very severe damage was confined to multi-storey buildings on the deep alluvium, while there was moderate damage in areas with alluvium to an intermediate depth and no damage in areas with surface rock.

It is interesting to note that if the buildings in the cities of Caracas and Manila had been limited to no more than 2 storeys and to earlier forms of construction there would have been little damage, probably no casualties, and no evidence of microzones, during these three earthquakes. Both cities had considerable shanty-town areas of very inferior construction, those in Caracas were built with hollow bricks and those in Manila were mainly of wood. None of these shanty-town buildings suffered any damage.

Microzone inertia effects are very pronounced during moderate earthquakes but can be expected to be less pronounced during very severe earthquakes, when plastic deformation of soil layers would limit resonance effects. If buildings are designed for these very severe earthquakes then during moderate earthquakes only non-structural damage should occur. If buildings are designed for less severe earthquakes then structural damage and possibly collapse could occur during the moderate earthquake in which severe microzone effects may occur。
In New Zealand terms the Wellington area might display severe microzone effects during relatively frequent, moderately severe, earthquakes. Since the buildings in the Wellington arcà are designed for high earthquake loads, such moderately sevore arthquakes should causo little structural damage but may result in expensive non-structural damage in microzono areas of high intensity. For the infrequent, very severe earthquakes the most important microzone effect: will probably bo sround failure; slips, rupture, or liquefaction.

The Auckland area might have severe microzone effects during relatively infrequent earthquakes of moderate severityo Since Auckland buildings are desicnod for lower carthruake loads there nay be the possibility of scvere structural damage or collapse in microzone areas of high ground acceleration.

\section{Plastic Reserve of Buildings}

The large plastic reserve which is normally assumed during earthquake-resistant design failed to materialize in the case of many recently damaged buildings. Firstly the plastic reserve of a building was often much lower than that of its individual components because overstrain and hence energy absorption was confined to a few of these components. Secondly the individual components of many buildings failed by a mechanism which absorbed little energy.

When a frame building is deformed laterally, column damage may be confined to a single storey. In many multi-storey buildings, particularly in Caracas, panels gave considerable support to all frame members except the first storey columns, where most panels are omitted for reasons of building utilization. Typical of these buildings was the 14-storey San Bosco, situated on the deep alluvium in Caracas. Initial moment damage occurred at the lower ends of the columns of the first storey. Before these lower end hinges rotated for enough to form hinges at the column tops the bases of some of the peripheral columns suffered severe crushing damage under gravity and overturning forces with the greatest damage at the weaker corner columns. The energy absorbed during the destruction of columns by crushing is probably much lower than the energy which can be absorbed by plastic hinges. The San Bosco came close to collapse by this low-plasticity mechanism.

The bending and more particularly the crushing damage of the columns was facilitated by light ties which unwrapped readily under damage conditions. It is likely that some or all of the 10 to 12 storey buildings which collapsed in Caracas did so by a similar lowplasticity mechanism.

A more extreme situation arose in the case of the 18 storey Caromay building. The long axis of this building was curved so that the stiffening action of panels above storey concentrated overturning forces on a very small number of columns which were severely crushed near their mid-height.

Two tall frame buildings, the 17-storey Residencia Union and the 18-storey Blue Palace were damaged with the formation of beam hinges rather than column hinges. This damage mechanism involved a considerable fraction of the beams and of the panels. Although damage was 
very extensire these buildings had a consider. able reserve of resistance after the earthquake.

Many frame buildings in Manila had two further factors which reduced the number of columns suffering plastic deformation. Many had deep exterior beams which stiffened exterior columns and hence increased their share of lateral loads. Furthermore, a number of buildings, including the collapsed Ruby Towers and the almost collapsed Philippine Bar Association bullding, had effective shear walls across one end further restricting the number of columns which deformed plastically.

Where coluinns had a large width-to-height ratio, often because the effective height was reduced by strong panels, the initial column damage was by diagonal tension cracking with low plasticity rather than by bending, which normally exhibits much higher plasticity. Severe cases of diagonal tension failure occurred during the May 1968 Tokachi-oki earthquake in northern Japan. Column shear failures were very severe in a number of 2 to 4 storey reinforced concrete school buildings. These buildings were less than 10 years old and were designed to resist a base shear of about 0.18 of gravity. The columns were considerably shortened by concrete panels and the primary failure was by diagonal tension cracks in the first storey columns. The low plastic reserve of this failure mechanism resulted in very severe damage. It is understood that Japanese experts now consider that design against diagonal tension failure should be based on twice the present base shear coefficients. Diagonal tension must be resisted by adequate transverse ties and stirrups. These ties must be secure against unwrapping under damage conditions and the spacing must be much less than the smaller column or beam dimension.

When a column or beam develops plastic hinges under end moments a high plasticity factor is dependent on effective containment of the concrete in the plastic region. The need for this containment has been established by many laboratory tests and has been demonstrated frequently during recent earthquakes. Concrete containment requires adequate closespaced ties with end anchorages which are effective even after the exterior concrete is spalled off and the interior concrete is cracked. Close-spaced spiral ties are particularly effective as transverse reinforcing for square or circular columns.

Inadequate ties have been an important factor in the observed failures of a large number of columns. Cases of damage under forces which were predominantly bending or shearing or crushing have been observed and also cases with combinations of these forces. Instances of tie steel failure in tension have been very rate. In almost every case the ties have unwrapped. A common error is excessive spacing between ties. There have been a number of instances of very irregularly placed ties with some spaces more than twice the design value. The effectiveness of properly placed spiral reinforcing was demonstrated in the case of some greatly overloaded columns in the B.B.A. building, Manila, Fig. 1 .

\section{Panel-Frame Interaction}

The earthquake resistance of many buildings was greatly changed by unreinforced panels of ceramic or concrete hollow blocks. In Caracas the panels were of very low strength bricks which usually contained about $80 \%$ voids. These panels were completely neglected during the deisgn of the reinforced concrete frames for seismic loads. These panels showed surprising strength, particularly when they had small or no openings and were framed by beams and columns. In the first storey there were usually few panels and these were shat tered in severoly at tacked buildings. Panels in the second and third storeys usually suffered some damage, but insufficient to allow plastic hinges to form in columns or beams. In general the panels had insufficient strength to cause direct damage to frame members. However their stiffening action greatly favoured column damage at a single storey level (usually storey one) rather than beam damage over several storeys, since the latter requires the simultaneous shattering of a much larger number of panels. Only for buildings with much higher resistance in the columns than in the beams, such as the 18-storey Residencia Union and the 19-storey Blue Palance, were beam hinges formed over several lower storeys. The se beam hinges were necessarily associated with severe panel damage over all the lower storeys of the two buildings.

In designing a reinforced - concrete frame building an attempt may be made to ensure that beam hinges, rather than column hinges, form during lateral deformations. This damage mechanism has the advantage that beam hinges involve several storeys and hence a greater absorption of energy and the further advantage that beams are free of axial loads which accelerate the collapse of a hinge. However even incomplete low-strength panels may give so much resistance to the formation of beam hinges that the mechanism is changed to the formation of column hinges at a single storey level. Somewhat strong panels may reduce the effective lengths of some columns and lead to their failure by diagonal tension cracking, a mechanism with a very low plastic reserve.

In the city of Manila the panels in reinforced concrete buildings were usually of concrete hollow blocks, although a few were ceramic hollow blocks containing about $50 \%$ voids. While some panels were complete, in most cases they either contained window openings or they extended only part way up the columns. When these buildings swayed under earthquake forces there was severe interaction between the rigid panels and the relatively flexible frames. During the 1968 earthquake direct interaction usually resulted in panel damage. During the apparently shorter period vibrations of the 1970 earthquake however, panel forces often caused direct damage to columns and in some cases caused their total failure. Such column failures, which result directly from panel forces, are particularly liable to result in total collapse of a building. Initial failure is usually by diagonal tension cracks in a limited number of columns at a single storey level, Fig. 2. Since such shear failures absorb little energy building vibrations continue at a high level so that the shear failures may progress to complete column failure under vertical loads and thence to the collapse of the building.

As the height of a building is increased the column strength is increased and there is 
the refore less likelihood of direcl clamage by a given type of panel. Direct altack on panc]s is therefore more screre for lower buildings. Such lower buildings were attacked more severoly during the 1970 earthquake and were associaled with more severe column damage. Whilo diroct column damage by concrete hollow-block panel. is characteristic of lower buildings an increase in panol strength would extend this form of attack to stronger columns and hence to taller buildings.

Panels which extend part way up columus are most likely to cause direct column damage. However even complete panols can causi shear failure in columns, after first separaling along their top edge and then failing at thoir upper corner. The panel then supperts the column over only part of its height and column failure in diagonal tension may occur once more. During the 1968 earthquake columns at the upper levels of the 11-storey Diamond Tower suffered moderate damage by concrete hollow block pancls, Fig. 3. During the 1970 earthquake the 8 -storoy United Building had several columns severely damaged by panel forces, Figs. 4 and 5 . As a result the building was close to total collapse.

\section{Shear Walls in Manila Buildings}

No attempt was made to increase the lateral resistance of the reinforced concrele frame buildings in Manila city by the inclusion of shear walls. However fire walls were provided where ever a building shared a boundary with another building and these were constructed as substantial reinforced-concrete structural walls. Many buildings had such structural walls on one or two sides. When a shear wall was located at one end of a long building it probably increased the severity of the transverse attack on the panels and the frame at the far end of the building. Indeed the 6-storey Ruby Towers which collapsed in 1968 and the 6-storey PBA building which almost collapsed were both long buildings with a shear wall across one end. Those long buildings which had a shear wall on a 1 ong side, such as the Diamond Tower, were effectively protected against longitudinal forces but often sustained damage from transverse forces.

A short (in plan view) longitudinal shear wall in the Trinity building increased its earthquake resistance by a method which holds great promise for frame buildings. The Trinity building is 7 storeys high with 6 bays by 4 bays. There is a transverse shear wall at one end. At the far end of one long side is a short longitudinal shear wall occupying only the $6 \mathrm{th}$ bay. The building frame had very deep box beams along three exterior walls and flexible interior columns. In the absence of the short shear wall it is probable that the first storey exterior columns would have suffered severe diagonal tension cracks on the long sides and across the end remote from the transverse shear wall. However, the short longitudinal wall limited the column damage and distributed it over storeys 2 to 5. Although the short shear wall made an important contribution to the earthquake resistance of the Trinity building it was evidently introduced for architectural rather than structural reasons.

\section{Repair and Strengthening in Manila}

After the 1968 earthquake, and before the
1970 earthyuake, a number of buildings had bow ropairnd and short shear walls had been addod to increase their earthquake resistanco. Those procecluros proved gonerally successful in resisting the 1970 carthquake and should proro rory offoctire if adopted al the jutial design stage.

For siructural ropair smal 1 cracks wor fillecl with a pressure grout of cpoxy resin and largo opon cracks wero carofully clearod of loose concroto and fildod with hardpack concreta. Where damage was sorere an addilinal steel cage was provided. Thuse repairs wore cridently successful in a number or mombers oxaminod aftor the 1970 earthequak.

Near the culds of the long Diamond Tower building, fig. 6, and of the long section of the Prarl Tower building short transrerse shear walls were provided to complement the longitudinal fire walls. Transverse shear walls were also introduced in single bays of the more nearly square Pearl Tower block. The Gorluner building is in the form or a largo lollow square and contains no fire walls. Hin... single-bay shear walls were added, and also 2 l-shaped shear walls which were associated with stairways and lift shafts. In intruducing the single-bay shear walls great pains were taken in an attempt to ensure that they were integral with the building frame and floor diaphragms. This integral action was certainly achieved during the moderately severe 1970 earthquake.

0:1" method of introducing shear walls was to remove all the non-structural panels in a single bay. The surface concrete was then chipped off the beams and columns to expose the main longitudinal steel on all sides of each opening. These openings were then filled with substantial reinforced concrete panels which contained vertical, horizontal, and diagonal steel。A substantial fraction of this panel steel was welded to the exposed main steel in the surrounding columns and beams. An attempt was made to give these shear walls a substantial footing but this was difficult to achieve in the existing buildings。

A second method adopted to introduce short shear walls was to cut out the beams as well as the panels between a pair of adjoining columns. In this case some of the shear-wall steel was welded to exposed floor-slab steel as well as some being welded to exposed column steel.

During the 1970 earthquake the Pearl Tower and the Diamond Tower suffered no significant structural damage and little non-structural damage. The Gocheco suffered moderate structural and non-structural damage and this was distributed over a substantial part of its height. The moderate damage and the large margin of safety against collapse were due in large measure to the strengthening shear walls.

\section{Increasing the Earthquake Resistance of Frame Buildings}

Short shear walls provide an attractive method of limiting non-structural damage and of providing a large resistance against collapse in reinforced concrete frame buildings.

While it would be possible to take all lateral loads and severely limit deformations by a set of substantial shear walls such a 
238

solution woula be considerably more expensive than a simple frame building and would of ten be functionally unacceptable. Another possible solution is to make a frame which is highly resistant with membors proportioned and steel detailed to ensure that hinges with a largo plasticily factor form near beam-ends. Panels would be flexible or separated from the frame. This solution lends $t o$ be expensivo, it applies considerable constraints to the proportioning of the structural frames, and may still orly utilize the energy absorption of plastic hinges at a few levels of a tall building before the onset of collapse.

Short shoar walls provide an at tractive alternative to the above methods of increasing earthquake resistance. The primary function of the short shear wall is lo ensure that the interfloor deflections at all storeys are of similar magnitude. Since these short shear walls need occupy only a moderate number of single bays they have little effect on the utilization of the structure. Panels should where possible be detailed so that a considerable interstorey deflection can occur before they are severely damaged. Since the short shear walls ensure that panels at all levels act simultaneously it requires a considerably more severe, and hence much less frequent, earthquake to cause severe panel damage. As a further protection against panel damage the short shear walls can be provided with a moment resistant base to further limit interstorey deflections particularly at the lower levels where they tend to be largest.

To provide high resistance against collapse beams and columns should be proportioned and reinforced to ensure that large deformations occur as plastic hinges, preferably in beams, rather than as diagonal tension cracks. The short shear walls ensure the simultaneous resistance of a very large number of plastic hinges and give the building a large plastic reserve. To ensure the largest possible plastic reserve it is essential to avoid a diagonal tension failure near the base of the short shear walls. The short walls should finally fail with rotation rather than translation of the base. The loss of plastic reserve which is suffered when a short shear wall fails in diagonal tension was demonstrated when a five-storey frame building was tested to destruction at the Building Research Institute in Tokyo。

If a design procedure accepts panel damage during very severe earthquakes steps should be taken to avoid casualties from falling masonry. A high-strength canopy should extend over the main exits and steps should be taken to prevent masonry from falling in stairways.

\section{References}

Falconer, B. H。 $1964:$ Niigata Earthquake, Japan 1.02 P.M. 16 June 1964. International Institue of Seismology and Earthquake Engineering, Tokyo, Japan.

Wood, F。 J. 1967: The Prince William Sound, Alaska, Earthquake of 1964 and Aftershocks, Vol. II. United States Government Printing Office, Washington, D. C.

Skinner, R。 I. 1968 : Engineering Study of Caracas Earthquake, Venuezuela, 29 July 1967.
New Zealand Department of Scientific and Industrial Research, Bul1。191。

Nielsen, NoN. and Nakagawa, K。 1968: The Tokachi-Oki Earthquakı, Japan, May 16 , 1968, A Proliminary Report on Damagi to Structures. Intornational Instituto or Seismology and Earthquake Engineering, Tokyn, Japan.

Omote, S., Osawa, Y., Skinner, T., and Yushimi, Y. 1969: Philjppines, Luzon Eartisfuake of 2 August 1968. Unesco, Paris Sorial No. 977.

Skinnor, I., Watabe, M. (submitled) Philippincs, Luzon Earthquaks of 7 April 1970, Unssiu, Paris.

Omote, S., Osawa, Yo, Skinnsr, I., Watabu, M., Yoshimi, Y. (Under Proparation) : Luzon Earthquakes, 2 August 1968, 7 April 1970。 International Institute of Seismology and Earthquake Enginecrine, Tokyo, Japan. 


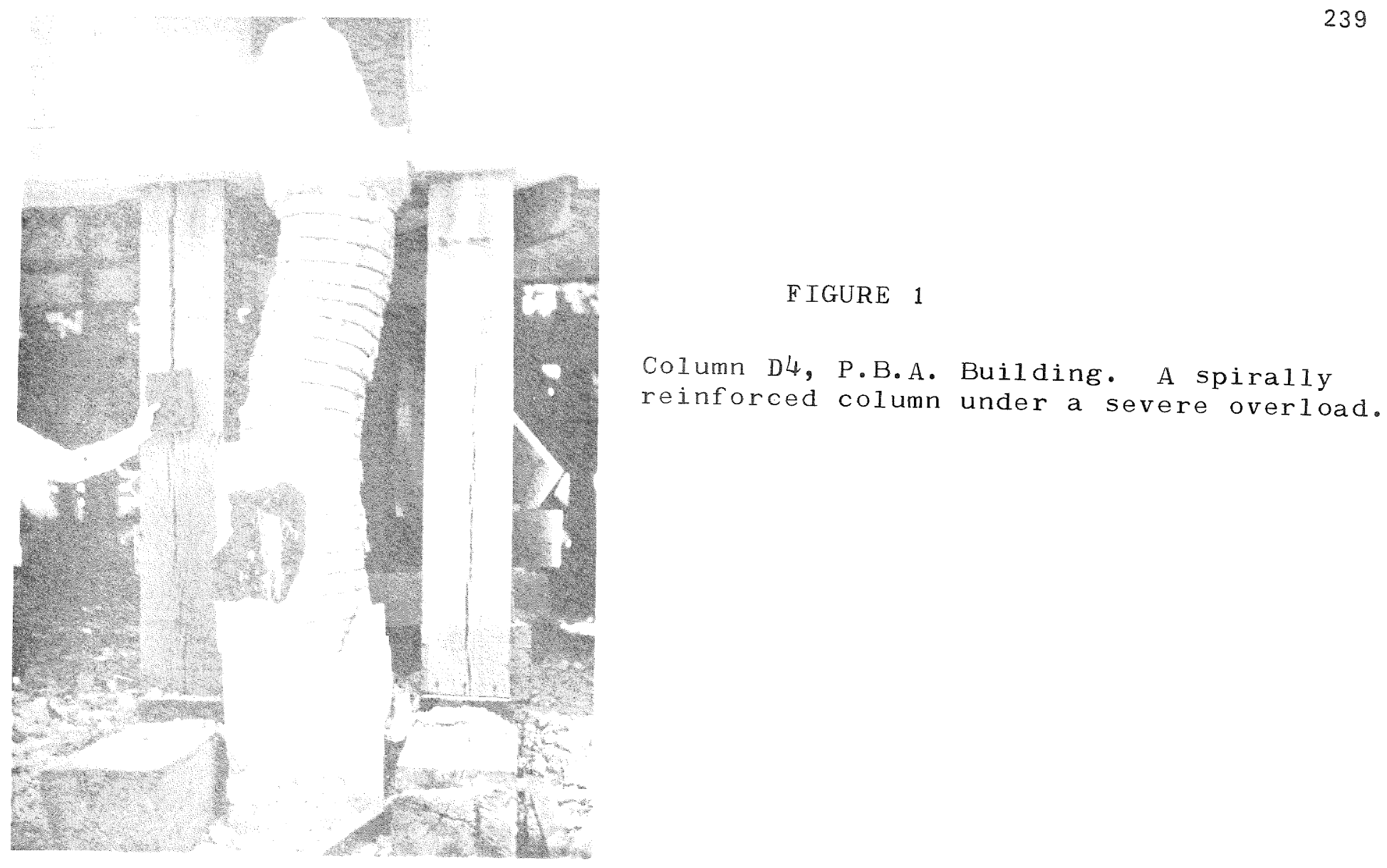

Photo V-3 Colum D4, R,B.A. Building;

compare photograph 11. 1968 report

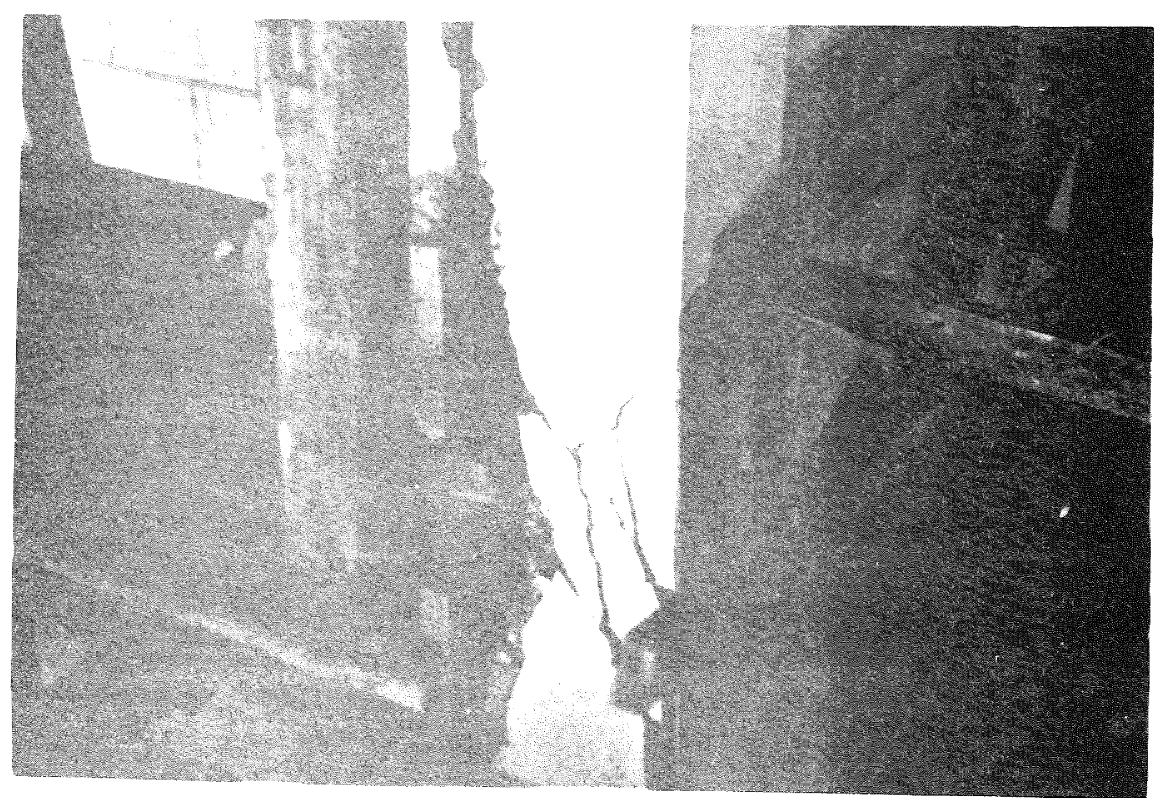

Photo V-24 Column shear damage by panel, Agonct110 Elementary School 


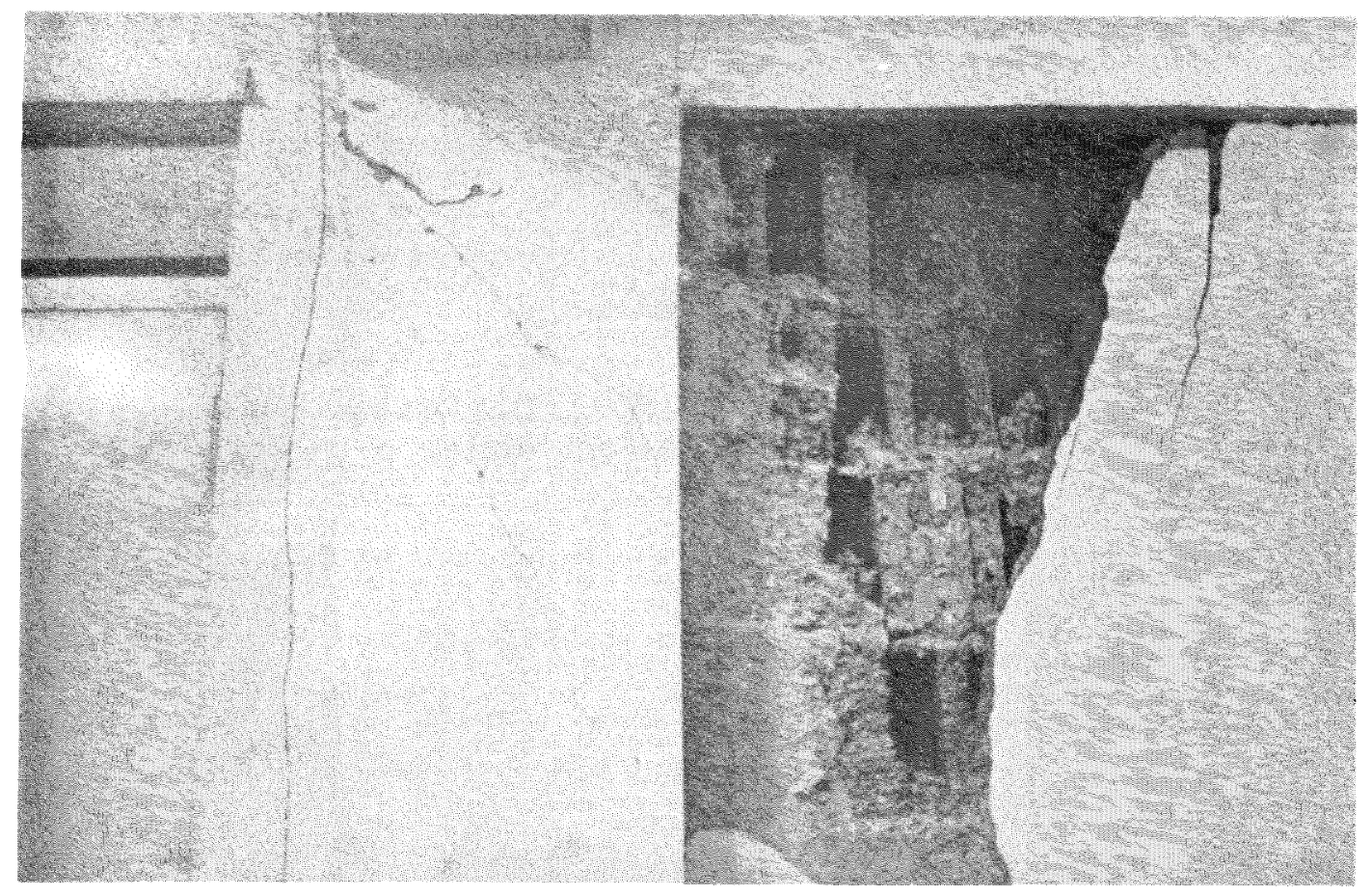

Figure 3

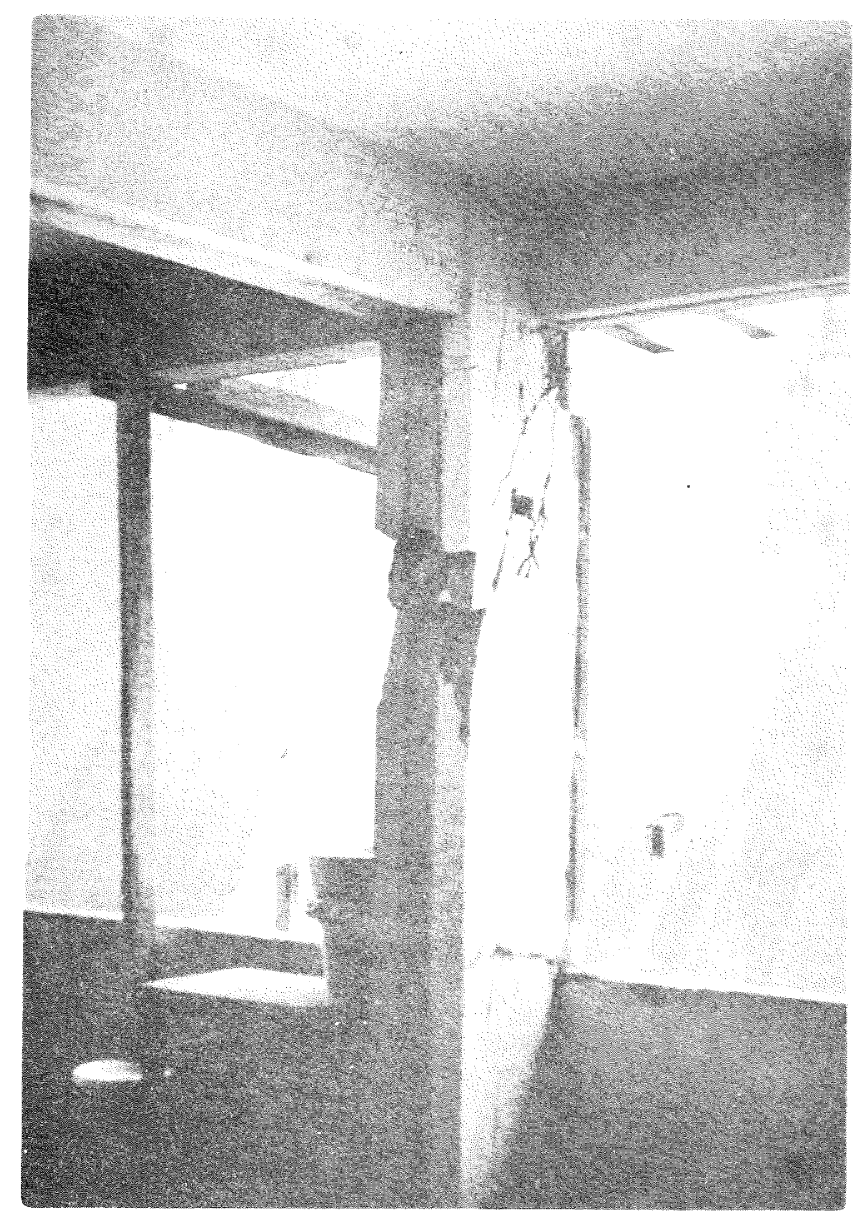

Diagonal tension cracks resulting from a damaged panel in Diamond Tower.

Figure 4

Diagonal tension cracks from a damaged panel in the United Building.

Photo Vom 32 Diagonal tension cracks in second-storey exterior colum, $G 7$, of United Building 
Figure 5

Composite drawing based on unrelated components showing assumed mechanism of column damage in the United Building.

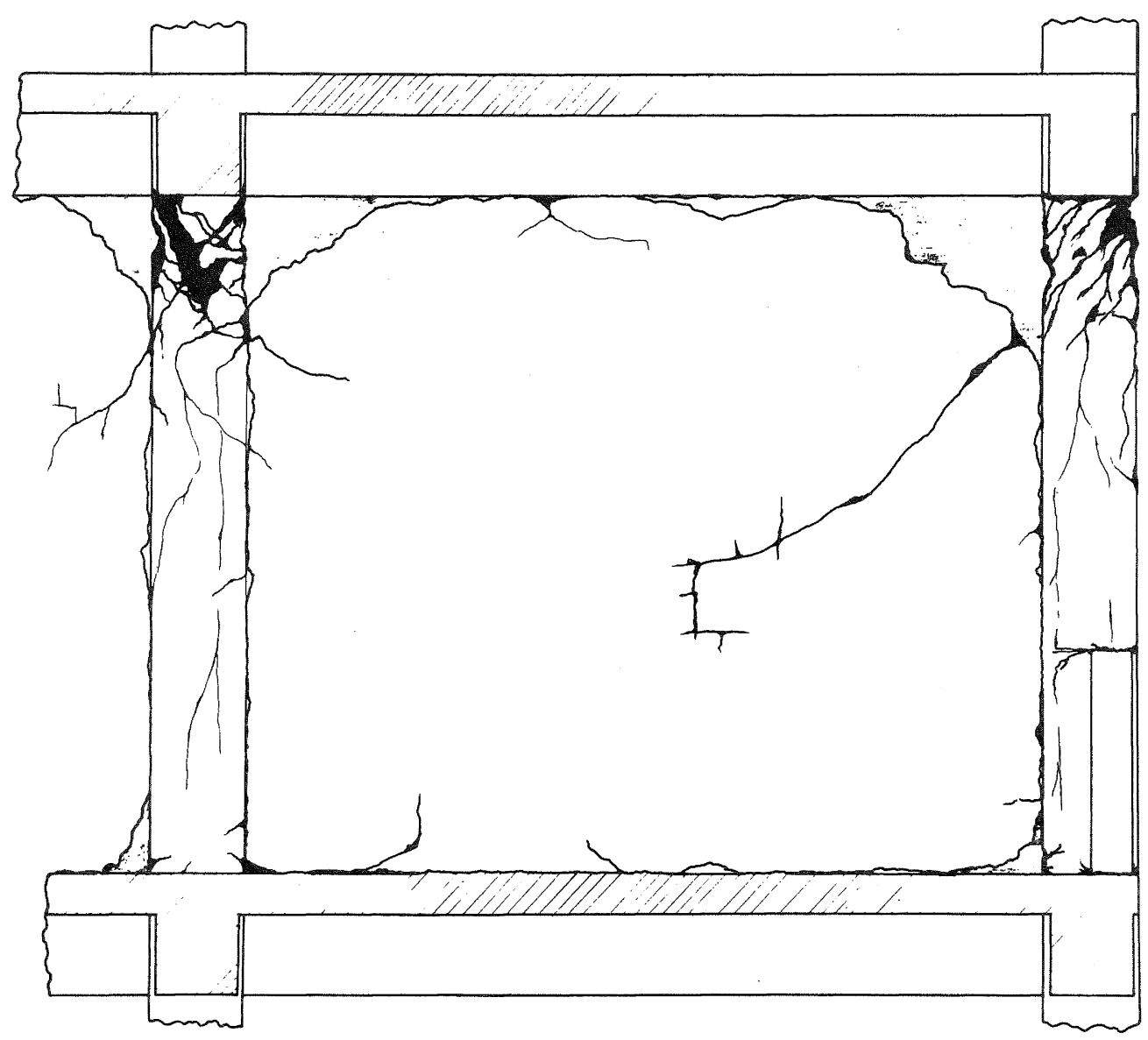


DIAMOND TOWER APARTMENTS

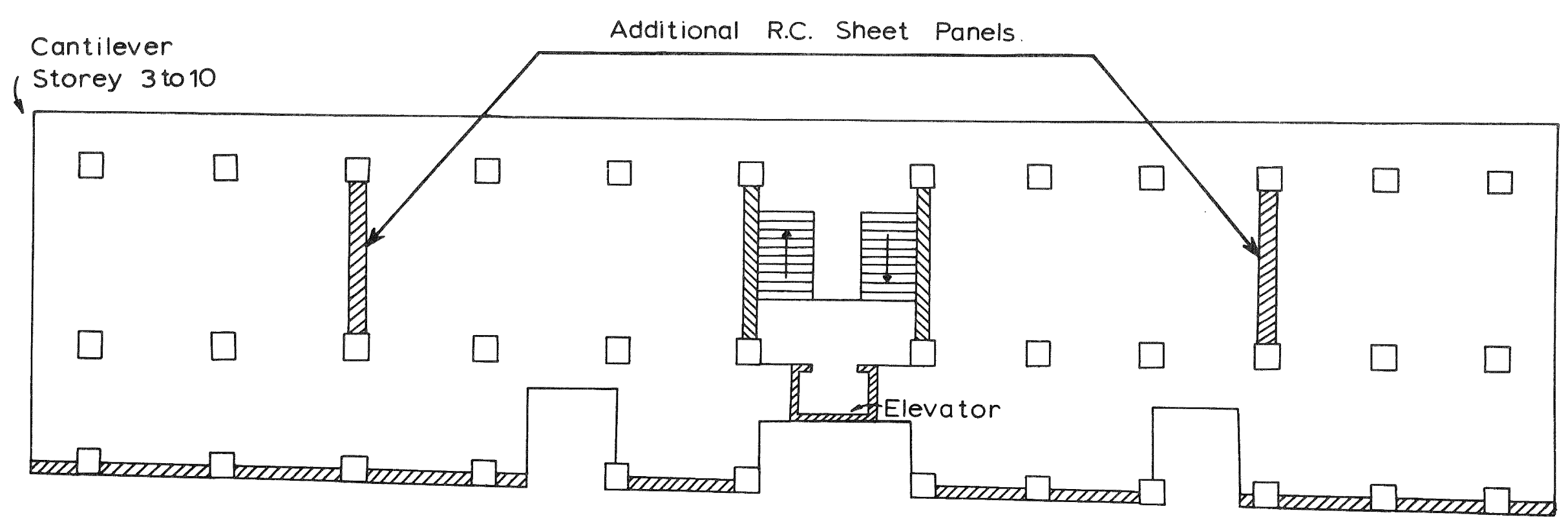

Typical Lower Column 28'x 28"

Typical Lower Beam 12" $128^{\prime \prime}$

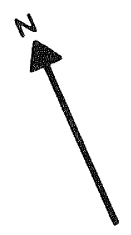
6

Figure 6 